\title{
Visual outcomes after implantation of a novel refractive toric multifocal intraocular lens
}

\section{Resultado visual após implante de uma nova lente intraocular multifocal refrativa tórica}

Talita Shimoda ${ }^{1}$, Gilberto Shimoda ${ }^{1}$, Wilson Takashi Hida², Celso Takashi Nakano², Antônio Francisco Motta ${ }^{2}$, Aline Silva Guimarães ${ }^{3}$, Patrick Frensel M. TZELIKIS ${ }^{3}$

\begin{abstract}
Purpose: To assess the postoperative outcomes of a novel toric multifocal intraocular lens (IOL) in patients with cataract and corneal astigmatism.

Methods: This prospective nonrandomized study included patients with cataract, corneal astigmatism, and a motivation for spectacle independence. In al patients, a Rayner M-flex ${ }^{\circledast} \mathrm{T}$ toric IOL was implanted in the capsular bag. Three months after surgery, the distance, intermediate, and near visual acuities; spherical equivalent; residual refractive astigmatism; defocus curve; and contrast sensitivity were evaluated. A patient satisfaction and visual phenomena questionnaire was administered to all patients.

Results: Thirty-four eyes of 18 patients were included in this study. Three month after surgery, the mean corrected distance visual acuity (logMAR) was $0.00 \pm 0.08$ at $6 \mathrm{~m}, 0.20 \pm 0.09$ at $70 \mathrm{~cm}$, and $0.08 \pm 0.11$ at $40 \mathrm{~cm}$. Uncorrected distance vision acuity was $20 / 40$ or better in $100 \%$ eyes. The preoperative mean refractive cylinder (RC) was -2.19 (SD: \pm 0.53 ). After a 3-month follow-up, the average RC was -0.44 D (SD: $\pm 0.27 ; p<0.001)$. Contrast sensitivity levels were high. At the last follow-up, $87.5 \%$ patients were spectacle-independent for near, intermediate, and distance vision, and approximately $44 \%$ patients reported halos and glare.

Conclusion: Toric multifocal IOL implantation in patients with cataract and corneal astigmatism using the Rayner M-flex ${ }^{\circledast}$ T toric IOL was a simple, safe, and accurate option. This technology provides surgeons with a feasible option for meeting patient expectations of an enhanced lifestyle resulting from decreased spectacle dependence.
\end{abstract}

Keywords: Astigmatism/surgery; Lens implantation, intraocular; Lenses, intraocular; Phacoemulsification; Polymethyl methacrylate; Refraction ocular; Visual acuity

\section{RESUMO}

Objetivo: Avaliar o resultado pós-operatório de uma nova lente intraocular (LIO) multifocal tórica implantada em pacientes com catarata e astigmatismo corneano. Métodos: Estudo prospectivo não randomizado envolvendo pacientes com catarata, astigmatismo corneano, e motivação para eliminar a dependência dos óculos. Em todos os casos, a lente intraocular tórica Rayner M-flex ${ }^{\circledR} T$ foi implantada dentro do saco capsular. Três meses pós-operatório foram avaliados: acuidade visual para longe, intermediário e perto; equivalente esférico; astigmatismo refracional residual; curva de defocus e sensibilidade ao contraste. Ao final do estudo um questionário referente à satisfação visual foi aplicado.

Resultados: Trinta e quatro olhos de 18 pacientes foram incluídos no estudo. Após 3 meses de pós-operatório, a acuidade visual corrigida para longe (logMAR) era de $0,00 \pm 0,08$ a $6 \mathrm{~m}, 0,20 \pm 0,09$ a $70 \mathrm{~cm}$ e 0,08 $\pm 0,11$ a $40 \mathrm{~cm}$. A acuidade visual sem correcão foi de 20/40, ou melhor, em 100\% dos olhos. A média do cilindro refracional pré-operatório era de -2,19 (DP: $\pm 0,53)$. Após o seguimento de 3 meses a média do cilindro refracional era de $-0,44 D(D P: \pm 0,27)(p<0,001)$. Os níveis de sensibilidade ao contraste foram elevados. Ao final do seguimento, $87,5 \%$ dos pacientes estavam independentes dos óculos para perto, intermediário e para longe, e aproximadamente $44 \%$ dos pacientes relatavam halos e glare.

Conclusão: Oimplante de umalenteintraocularmultifocal em pacientes com catarata e astigmatismo corneano utilizando a lente intraocular tórica Rayner M-flex ${ }^{\circledast} T$ foi uma opção simples, segura e acurada. Essa nova tecnologia oferece ao cirurgião uma maneira passivel de se atingir as expectativas dos pacientes em relação a qualidade de vida em razão de uma menor dependência dos óculos.

Descritores: Astigmatismo/cirurgia; Implante de lente intraocular; Lentes intraoculares; Facoemulsificação; Polimetil metacrilato; Refração ocular; Acuidade visual

\section{INTRODUCTION}

The goal of modern cataract surgery is to gain spectacle independence for distance, intermediate, and near vision, which can be achieved with the implantation of multifocal intraocular lenses (IOLs). However, approximately 15\%-29\% cataract patients have more than 1.50 diopters (D) of corneal or refractive astigmatism ${ }^{(1-3)}$. A residual astigmatism error of 1.50 to $3.0 \mathrm{D}$ after cataract surgery may decrease uncorrected visual acuity (UCVA) to 20/70 or 20/100 and may interfere with spectacle independence after multifocal IOL implantation ${ }^{(4)}$.

To overcome this problem, various surgical options to control astigmatism during cataract surgery are available ${ }^{(4,5)}$. Patients with a considerable amount of corneal astigmatism who wish to undergo multifocal IOL implantation have several options, including a clear corneal cataract incision along the steep meridian ${ }^{(5)}$, astigmatic keratotomy $(A K)^{(6,7)}$, opposite clear corneal incisions ${ }^{(8)}$, limbal relaxing incisions ${ }^{(9)}$, and, of late, toric multifocal IOL implantation to decrease astigmatism after cataract surgery ${ }^{(10)}$.

Toric multifocal IOLs offer the opportunity to correct astigmatism and achieve spectacle independence at all distances in patients with corneal astigmatism with only one procedure. This study assessed the visual function after cataract surgery and implantation of a toric multifocal IOL (Rayner M-flex ${ }^{\circledR} T$ toric) in a small single-site series of 34 eyes in 18 patients.

\section{METHODS}

This prospective study included patients with age-related cataract, corneal astigmatism of at least $1.00 \mathrm{D}$ (measured by keratometry), normal findings in ophthalmological examination besides senile cataract, an unsatisfactory correction with glasses, and a motivation
Submitted for publication: August 15,2013

Accepted for publication: December 1, 2013

Study conducted at Centro de Microcirurgia Ocular Atibaia (CEMOA), Atibaia, SP, Brazil.

Centro de Microcirurgia Ocular Atibaia (CEMOA), Atibaia, SP, Brazil.

Ophthalmology Department, Faculdade de Medicina, Universidade de São Paulo (USP), São Paulo, SP, Brazil.

${ }^{3}$ Brasília Ophthalmologic Hospital (HOB), Brasília, DF, Brazil.
Funding: No specific financial support was available for this study

Disclosure of potential conflicts of interest: None of the authors have any potential conflicts of interest to disclose.

Corresponding author: Patrick F. M. Tzelikis. SQN 203, Bloco G - Apto. 405 - Brasília (DF) 70833-070 - Brazil - E-mail: tzelikis@terra.com.br

ClinicalTrials.gov Identifier: NCT01505816 
for spectacle independence. Written informed consent was obtained from all patients before surgery, and the study was approved by the local ethics committee. All the procedures were in accordance with the ethical standards of the responsible committee on human experimentation and the Helsinki Declaration of 1975. Exclusion criteria were previous ocular surgery and irregular corneal astigmatism.

Before surgery, patients underwent extensive ophthalmological examination, including the measurement of uncorrected distance visual acuity (UDVA), corrected distance visual acuity (CDVA), refraction, slit-lamp examination, fundoscopy, corneal topography (EyeSys unit, version 3.03; EyeSys Technologies, Houston, Texas), and biometry with the IOLMaster partial coherence interferometry device (Carl Zeiss Meditec AG, Jena, Germany). The targeted postoperative refractive error was the closest to $0.0 \mathrm{D}$.

\section{IOL}

All patients received a Rayner M-flex ${ }^{\circledR}$ toric IOL (model 638F M-flex ${ }^{\circledR}$ T, Rayner IOLs, Ltd., UK). This multifocal aspheric IOL is made of hydrophilic acrylate. It is a multizoned, refractive, aspheric IOL with either 4 or 5 annular zones (depending on IOL base power). The optic diameter is $6.25 \mathrm{~mm}$ and the overall diameter is $12.5 \mathrm{~mm}$. Available spherical powers range from +14.0 D to +32.0 D in 0.50-D increments and include a near addition (add) of $+3.00 \mathrm{D}$. Cylinder powers range from +1.00 to $+6.00 \mathrm{D}$ in 0.50-D increments. The IOL power was calculated using an online calculator.

\section{Surgical techNique}

All patients were operated upon by the same surgeon using identical procedures. Before surgery, corneal reference marks were placed at $0^{\circ}$ and $180^{\circ}$ using a toric reference marker, with the patient sitting upright to correct for cyclotorsion. Next, the desired alignment axis for the toric IOL was intraoperatively marked with an angular graduation instrument. Phacoemulsification was performed using the Infinite (Alcon Surgical) Vision system. All IOLs were inserted in the capsular bag with the injector system. The toric IOL was implanted and rotated until the IOL markings agreed with the alignment marking. Postoperative follow-up was at 1 day and 1 and 3 months after surgery.

\section{OUtCOME MEASURES}

Postoperative evaluation was performed at 3 months. UDVA and CDVA were assessed using the 100\% contrast Early Treatment Diabetic Retinopathy Study chart. Uncorrected intermediate visual acuity (UIVA) for intermediate vision was assessed at $70 \mathrm{~cm}$, and the uncorrected near visual acuity (UNVA) for near vision was assessed at $40 \mathrm{~cm}$ (Near reading chart, Presby Corp.). A binocular defocus curve was constructed using the Early Treatment of Diabetic Retinopathy Study (ETDRS) chart at $4 \mathrm{~m}$. The cylinder axis of the IOL was measured at the slit lamp using the beam protractor after full mydriasis. The mean of the absolute $\mathrm{IOL}$ degrees that were off-axis was determined.

Contrast sensitivity was measured using the CSV-1000 HGT instrument (VectorVision, Inc. Greenville, OH, USA), which presents a translucent chart divided into 4 cycles with spatial frequencies of 3,6 , 12 , and 18 cycles per degree (cpd). All measurements were obtained under mesopic $\left(5 \mathrm{~cd} / \mathrm{m}^{2}\right)$ and photopic $\left(85 \mathrm{~cd} / \mathrm{m}^{2}\right)$ conditions. Examinations were unilaterally performed at a distance of $2.5 \mathrm{~m}$, with the corrected visual acuity (BCVA) and an undilated pupil.

Patient satisfaction and quality of life were assessed by a simple questionnaire. All patients were interviewed 3 months after surgery. Patients were asked about visual disturbances, visual lifestyle activities, spectacle use, and procedural satisfaction.

All data analyses were performed using SPSSX statistical programs (SPSS Inc, Chicago, IL, USA). The normality of all data samples was first checked using the Kolmogorov-Smirnov test. When parametric analysis was possible, Student's t-test for paired data was used for all parameter comparisons between pre- and postoperative examinations. When parametric analysis was not possible, the Wilcoxon rank-sum test was applied. Any differences showing a $p$-value of $<0.05$ (i.e., at the $5 \%$ level) were considered statistically significant.

\section{RESULTS}

The study enrolled 18 patients (34 eyes). Sixteen patients had bilateral Rayner M-flex ${ }^{\circledast} T$ toric multifocal IOL implantation; the other 2 received a Rayner $M$-flex ${ }^{\circledR}$ multifocal IOL because they had mild astigmatism (<1.0 D). Three patients were men (16.7\%) and 15 were women (83.3\%), with a mean age of 69.44 years (range, 52-86 years; SD, \pm 8.9 ). All patients had mild cataract at presentation. The mean spherical power of the implanted toric multifocal IOLs was $+20.32 \pm 3.1 \mathrm{D}$ (range, 14.00-25.00 D). The mean preoperative axial length $(A L)$ was $23.22 \pm 0.8 \mathrm{~mm}$ (range, 21.39-26.19 mm). All patients were followed-up for 3 months.

\section{VISUAL ACUITY AND REFRACTION}

Table 1 shows the distance, intermediate, and near visual acuities. The postoperative UDVA was 20/40 (0.3 logMAR) or better in 34 eyes (100\%), 20/30 (0.18 logMAR) or better in 31 eyes (91.2\%), and 20/25 (0.10 logMAR) or better in 30 eyes (88.2\%), while CDVA was 20/40 or better in 34 eyes (100\%) and 20/25 or better in 32 eyes (94.1\%). Figure 1 shows the binocular defocus curve with 2 peaks of optimum CDVA at $0.00 \mathrm{D}$ and $-2.75 \mathrm{D}$.

Table 1. Mean preoperative and postoperative visual acuity and refraction (logMAR)

\begin{tabular}{lccc}
\hline & \multicolumn{3}{c}{ Mean \pm SD } \\
\cline { 2 - 4 } & Preop & Postop & p-value \\
\hline UDVA & $0.51 \pm 0.33$ & $0.03 \pm 0.09$ & $<0.001$ \\
CDVA & $0.13 \pm 0.13$ & $0.00 \pm 0.08$ & $<0.001$ \\
UIVA & - & $0.22 \pm 0.09$ & - \\
DCIVA & - & $0.20 \pm 0.09$ & - \\
UNVA & - & $0.10 \pm 0.13$ & - \\
DCNVA & - & $0.08 \pm 0.11$ & - \\
SE (D) & $-0.24 \pm 1.59$ & $0.11 \pm 0.40$ & 0.21 \\
Refractive cylinder (D) & & & \\
$\quad$ Mean & $-2.19 \pm 0.53$ & $-0.44 \pm 0.27$ & $<0.001$ \\
Range & -1.25 to -3.25 & 0.00 to -1.00 & \\
\hline
\end{tabular}

UDVA $=$ uncorrected distance visual acuity, CDVA = corrected distance visual acuity, UIVA= uncorrected intermediate visual acuity, DCIVA= distance-corrected intermediate visual acuity, UNVA= uncorrected near visual acuity, DCNVA= distance-corrected near visual acuity, $\mathrm{SE}=$ spherical equivalent.

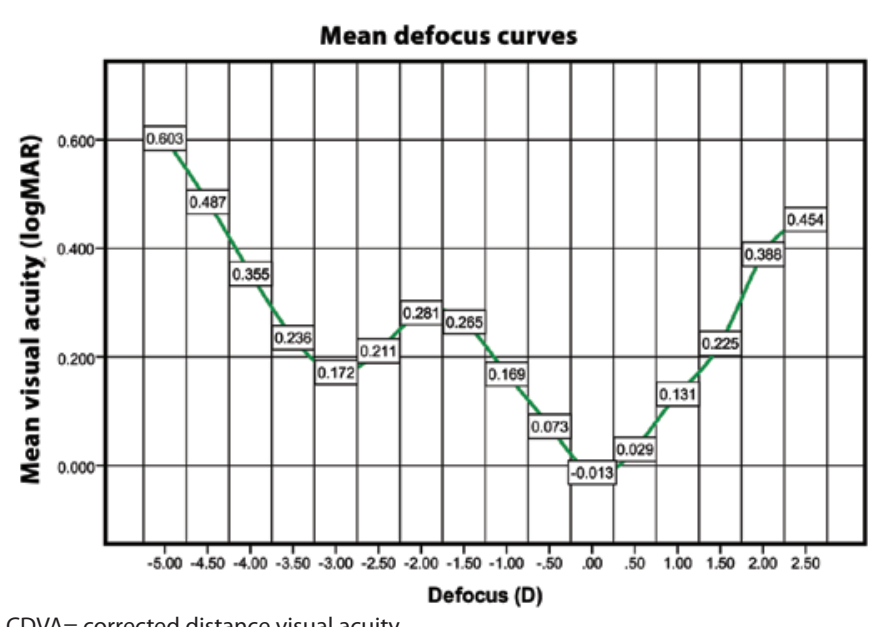

CDVA= corrected distance visual acuity.

Figure 1. Defocus curve (mean binocular CDVA as a function of diopters of defocus). 
The average SE of these eyes was $-0.24 \mathrm{D}$ (range, $-2.75-+3.00 \mathrm{D}$; $\mathrm{SD}, \pm 1.59$ ) at referral and 0.11 (range, $-1.00-+1.25 \mathrm{D}$; $\mathrm{SD}, \pm 0.40$; $p=0.21$ ) at 3 months after surgery. The average refractive cylinder of these eyes was $-2.19 \mathrm{D}$ (range, $-1.25--3.25 \mathrm{D} ; \mathrm{SD}, \pm 0.53$ ) at referral and $-0.44 \mathrm{D}$ (range, $0.00--1.00 \mathrm{D} ; \mathrm{SD}, \pm 0.27 ; p<0.001$ ) at 3 months. Almost $95 \%$ eyes had a postoperative residual refractive astigmatism of -0.75 D or less.

Corneal topography values at presentation were recorded for all eyes. The average flatter corneal meridian topography was $43.21 \mathrm{D}$ (range, 40.40-45.96 D; SD, \pm 1.20 ), and the average steeper corneal meridian topography was 45.57 D (range, 42.74-47.74 D; SD, \pm 1.27 ). The average topographic astigmatism was 2.29 D (range, 1.36-3.19 D; $\mathrm{SD}, \pm 0.52$ ), which increased to $43.25 \mathrm{D}$ (range, 40.32-45.93 D; $S D, \pm 1.25)$ at 3 months after surgery. The average steeper corneal meridian topography was $45.51 \mathrm{D}$ (range, 42.64-47.74 D; SD, \pm 1.26 ), and the average topographic astigmatism was $2.16 \mathrm{D}$ (range, 1.38-3.16 D; $\mathrm{SD}, \pm 0.54 ; p>0.05)$.

\section{Misalignment}

Three months after surgery, the mean error in $\mathrm{IOL}$ alignment was $2.34 \pm 2.33^{\circ}$ (range, $\left.0-9^{\circ}\right)$. The mean error in $\mathrm{OOL}$ alignment was more than $5^{\circ}$ in 5 eyes (17.6\%). No IOL was misaligned by $10^{\circ}$ or more.

\section{Contrast Sensitivity}

Figure 2 shows the mean log monocular contrast sensitivity values under photopic and mesopic conditions at 3 months after surgery. The mean contrast sensitivity levels in photopic and mesopic conditions were $1.60 \pm 0.11$ and $1.39 \pm 0.16$, respectively, at $3 \mathrm{cpd}$, $1.69 \pm 0.12$ and $1.44 \pm 0.21$, respectively, at $6 \mathrm{cpd}, 1.12 \pm 0.36$ and $0.93 \pm 0.41$, respectively, at $12 \mathrm{cpd}$, and $0.57 \pm 0.42$ and $0.37 \pm 0.41$, respectively, at $18 \mathrm{cpd}$

\section{Patient satisfaction and spectacle dependency}

All 16 patients with bilateral Rayner M-flex ${ }^{\circledR} T$ toric IOLs completed the questionnaire. Table 2 shows patient-reported spectacle dependence; satisfaction with distance, intermediate, and near vision; and the incidence of halos and glare. Three months after cataract surgery, no eye required a second procedure. At the last follow up, 14 patients (87.5\%) were spectacle-independent for near, intermediate, and distance vision and were very satisfied with their quality of vision without glasses. Good distance and near vision were reported by all patients.

\section{DISCUSSION}

Clinical trials evaluating the clinical, optical, functional, and quality-of-life outcomes after implantation of these new-generation IOLs found that the participants had improved near vision and

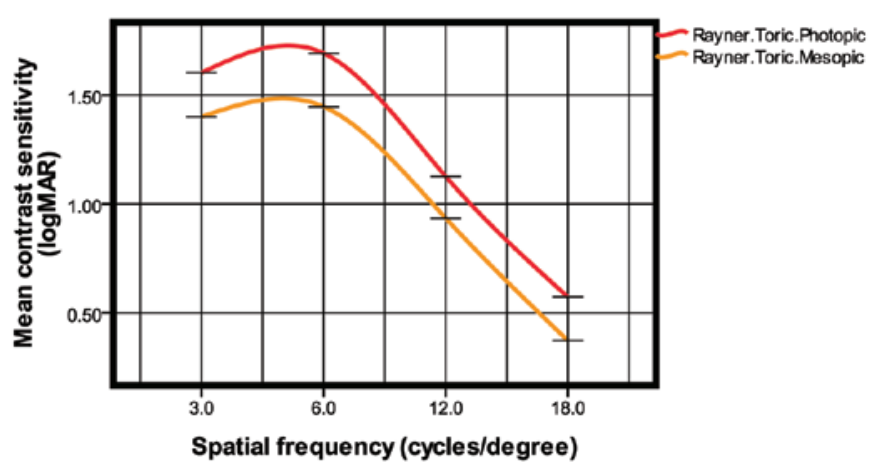

Figure 2. Mean log contrast sensitivity values at 3 months.
Table 2. Subjective symptoms and spectacle-dependence 3 months after surgery

\begin{tabular}{lc}
\hline Parameter & Mean score \pm SD \\
\hline Satisfaction with distance vision (from 0 to 10) & $9.28 \pm 1.37$ \\
Satisfaction with intermediate vision (from 0 to 10) & $8.97 \pm 2.41$ \\
Satisfaction with near vision (from 0 to 10) & $8.44 \pm 2.06$ \\
\hline Spectacle dependence (number of patients) & Number of patients (\%) \\
Never & $16(88.9 \%)$ \\
Sometimes & $2(11.1 \%)$ \\
Always & $0(0.0 \%)$ \\
Halos & Number of patients (\%) \\
None & $10(55.6 \%)$ \\
Mild & $5(27.7 \%)$ \\
Moderate & $3(16.7 \%)$ \\
Severe & $0(0.0 \%)$ \\
Glare & Number of patients (\%) \\
None & $10(55.6 \%)$ \\
Mild & $4(22.2 \%)$ \\
Moderate & $3(16.7 \%)$ \\
\hline Overe & $1(5.5 \%)$ \\
\hline
\end{tabular}

Overall satisfaction, range from 0 (least satisfied) to 10 (most satisfied).

good distance vision ${ }^{(10-13)}$. Although patients with these IOLs report less limitation in visual function and less spectacle dependency compared with patients with monofocal IOLs $s^{(14)}$, some have reported dissatisfaction with the outcomes that are mostly related to visual aberrations such as halos, glare, and dysphotopsia(15).

After cataract surgery, even a relatively low amount of uncorrected astigmatism can significantly decrease visual acuity in eyes with multifocal IOLs, which will further decrease the ability to perform low-contrast tasks ${ }^{(16,17)}$. However, today's cataract patients are more demanding, and they usually seek total visual rehabilitation and total independence from spectacles. These requirements have been the motivating factor in the development of toric multifocal IOLs. These IOLs were designed to compensate for corneal astigmatism and the loss of accommodative ability after cataract extraction.

In the current study, we evaluated visual and refractive outcomes, contrast sensitivity, and patient satisfaction after Rayner M-flex toric multifocal IOL implantation. At present, there are only 4 types of toric multifocal IOL models available: diffractive ReSTOR IQ toric IOL (Alcon Laboratories, Inc.), diffractive AT Lisa toric IOL (Carl Zeiss Meditec AG), Lentis Mplus toric IOL (Oculentis $\mathrm{GmbH}$ ), and refractive M-flex TIOL (Rayner Intraocular Lens Ltd.).(18). So far, to our knowledge, no study of the Rayner M-flex TIOL has been published.

Nontoric Rayner multifocal IOL implantation has been evaluated in a few studies ${ }^{(19)}$. This IOL has the same platform as the Rayner M-flex T IOL. Cezón Prieto and Bautista ${ }^{(19)}$ studied the Rayner M-flex 630F +3.00 D IOL and found a mean monocular CDVA of 0.03 logMAR (approximately 20/20) 12 months after surgery; 100\% eyes had a CDVA of 0.30 logMAR (20/40) or better, while 100\% eyes had a CDVA of 0.00 logMAR (20/20) or better. The toric Rayner monofocal IOL has also been evaluated in a few studies ${ }^{(20)}$. In a study of the Rayner T-flex 623T toric IOL, some authors ${ }^{(20)}$ found a mean CDVA of 0.19 logMAR (approximately 20/30) 4 months after surgery; 96.6\% eyes had a CDVA of 0.30 logMAR (20/40) or better, $81.8 \%$ eyes had a CDVA of 0.18 logMAR (20/30) or better, and $21.1 \%$ eyes had a CDVA of 0.00 logMAR (20/20) or better. Our study found a good CDVA (mean 0.00 logMAR), with all patients having a CDVA of 20/25 or better at 3 months. There are few published studies describing refractive 
outcomes after toric multifocal IOL implantation ${ }^{(10,13,21)}$. Other authors ${ }^{(10,13)}$ reported a binocular logMAR CDVA of -0.06 and 0.05 after 3 months of follow-up using the AT Lisa toric multifocal IOL.

Uncorrected outcomes were also good, with 90\% patients achieving a UDVA of 20/25 or better in our study. Cezón Prieto and Bautista ${ }^{(19)}$ found a mean UDVA of 0.09 logMAR (approximately 20/25) 12 months after surgery using the Rayner M-flex 630F IOL, with $100 \%$ eyes achieving a UDVA of 0.30 logMAR (20/40) or better and 75\% eyes achieving a UDVA of 0.00 logMAR (20/20) or better. Similar results were reported by Viesser et al. ${ }^{(10)}$ using the AT Lisa toric multifocal IOL with a mean monocular logMAR UDVA of 0.043 months after surgery; 98\% eyes had a UDVA of 0.30 logMAR (20/40) or better and $71 \%$ eyes had a UDVA of 0.10 logMAR (20/25) or better.

Recently, there has been a trend toward decreasing the power of the near add (from +4.00 D to +3.00 D) in some models of multifocal IOLs to improve intermediate vision or expand reading distance ${ }^{(19,21-23)}$. At 3 months, the mean monocular UIVA and distance-corrected intermediate visual acuity (DCIVA) in our study were 0.22 logMAR and 0.20 logMAR, respectively. These findings are slightly better than those of Viesser et al. ${ }^{(10)}$, who reported a 3-month monocular intermediate vision (at $60 \mathrm{~cm}$ ) with toric multifocal IOL of $0.40 \log M A R$ with and without correction. For intermediate distances, different models of multifocal IOL with a +3.00-D add power have shown similar results. Alfonso et al. ${ }^{(22)}$, in a study of the AcrySof ReSTOR SN6AD1, found mean binocular UIVA and DCIVA logMAR values of 0.165 and 0.147 at $70 \mathrm{~cm}$ after 6 months of follow-up. Muñoz et al. ${ }^{(23)}$ studied the Lentis Mplus LS-312 multifocal IOL and found a IogMAR UIVA and DCIVA of 0.13 and 0.14 at $1 \mathrm{~m} 6$ months after surgery. Cezón Prieto and Bautista ${ }^{(19)}$ reported a mean UIVA and DCIVA value of 0.15 logMAR in eyes with Rayner M-flex IOL. This was consistent with our finding that the majority of patients did not use spectacles for intermediate vision because of the excellent visual acuity between 50 and $70 \mathrm{~cm}$.

In our study, the Rayner M-flex T IOL with +3.00 D add provided high performance for near vision; the mean monocular UNVA was 0.10 logMAR and the mean DCNVA was 0.08 logMAR at 3 months. The near vision achieved with the Rayner M-flex T IOL was comparable to that with other multifocal IOLs $s^{(10,12,13,22,23)}$. In the study by Viesser et al. ${ }^{(10)}$, the mean UNVA was 0.20 logMAR. In another study of toric multifocal IOL by Alió et al..(13) the mean postoperative UNVA and CDNVA was 0.24 and $0.24 \log M A R$, respectively, at 3 months. Cezón Prieto and Bautista ${ }^{(19)}$ reported a UNVA value of 0.28 logMAR in eyes implanted with Rayner M-flex IOL. Similar results (binocular logMAR DCNVA, approximately 0.10) were reported by Fujimoto et al. ${ }^{(24)}$, who used the multifocal refractive Array SA40N IOL (Abbott Medical Optics, Inc.) and by Alió et al. ${ }^{(25)}$, who used the multifocal refractive-diffractive Acri. LISA 366D (Carl Zeiss Meditec AG) and the AcrySof ReSTOR SN6AD3 (Alcon Laboratories, Inc.).

The defocus curve for the Rayner M-flex $T$ IOL was consistent with the above findings, with a V-shaped curve with 2 peaks of maximum vision, 1 at distance (around a 0.00-D defocus level) and 1 at near (approximately -2.75 D defocus level). Between these 2 peaks, acceptable vision was maintained, resulting in acceptable intermediate vision. IOL performance for distance was similar to that with a monofocal IOL, with a logMAR acuity of approximately 0.00 . The IOL provided a logMAR intermediate acuity of approximately 0.20-0.30 between $50 \mathrm{~cm}$ and $70 \mathrm{~cm}$ and had the best logMAR near vision between $33 \mathrm{~cm}$ and $40 \mathrm{~cm}$. When considering the defocus curve for other multifocal IOLs, the range of focus for functional vision extended approximately from +1.0 D to -3.5 for $+3.0-\mathrm{D} I O L^{(10,22)}$.

According to slit-lamp examination, the mean misalignment of Rayner M-flex TIOL was $2.34 \pm 2.33^{\circ}$, with no IOL off-axis by more than $10^{\circ}$ at 3 months. We found the Rayner M-flex T IOL to be stable once positioned in the capsular bag. The amount of rotation of different toric IOL models is reported to be between $0^{\circ}$ and $20^{\circ}(26)$. The FDA trial of the AcrySof SA60T toric IOL compared 244 patients with a control group of 250 patients who received the nontoric AcrySof SA60AT
IOL. The former exhibited excellent rotation stability, with a mean rotation of less than $4^{\circ}$ from the initial alignment at 12 months after surgery. Rotation misalignment was $10^{\circ}$ or less in $97 \%$ patients and $5^{\circ}$ or less in $81 \%$ patients. Zuberbuhler et al..$^{(27)}$ subsequently reported a large series of AcrySof SN60T toric IOLs in 44 eyes. The mean toric $\mathrm{IOL}$ axis rotation was $2.2 \pm 2.2^{\circ}$, and $95 \% \mathrm{IOL}$ were within $5^{\circ}$ of the targeted axis. The current study of the rotational stability of the Rayner M-flex T toric IOL showed nearly identical results; the mean rotation was less than $4^{\circ}$, with $100 \% \mathrm{IOL}$ showing a rotation of $10^{\circ}$ or less. Our results were comparable with those in studies of the AcrySof toric IOL. Intraoperative positioning of toric IOLs with greater accuracy was necessary to achieve the most optimum cylinder correction in all patients $(21,26,27)$

The Rayner M-flex T is a refractive toric multifocal IOL with a multizone design that can cause loss of contrast sensitivity because of the distribution of total available light between several focal points. Patients with multifocal IOLs may therefore be more sensitive to changes in contrast and have been reported to have lower contrast sensitivity compared with the normal population ${ }^{(28)}$. Several studies ${ }^{(22,23,25,28)}$ have reported lower photopic contrast sensitivity with a multifocal IOL than with a monofocal IOL; however, the contrast sensitivity was still in the normal range. The results in our study confirmed these results. We obtained contrast sensitivity values under mesopic and photopic conditions that were similar to those obtained by Cezón Prieto and Bautista ${ }^{(19)}$, Montés-Micó et al. ${ }^{(28)}$, and de Vries et al. ${ }^{(29)}$. In a normal population, contrast sensitivity levels measured with the CSV-1000 system were $1.56 \pm 0.15$ at $3 \mathrm{cpd}, 1.80 \pm 0.16$ at $6 \mathrm{cpd}, 1.50 \pm$ 0.15 at $12 \mathrm{cpd}_{\text {, and }} 0.93 \pm 0.25$ at $18 \mathrm{cpd}^{(30)}$. This indicated that the contrast sensitivity after Rayner M-flex T implantation was comparable with that in the normal population at 2 spatial frequencies ( 3 and $6 \mathrm{cpd}$ ) and decreased at high spatial frequencies (12 and $18 \mathrm{cpd}$ ) under photopic and mesopic conditions.

\section{CONCLUSIONS}

The results of our study showed that implantation of the Rayner M-flex T IOL effectively decreased visually significant keratometric astigmatism and spectacle-dependence after cataract surgery, with acceptable low rates of IOL misalignment. Further studies on the efficacy of this toric multifocal IOL in cataract surgery are recommended with larger sample sizes and longer follow-ups.

\section{REFERENCES}

1. Hoffmann PC, HützW. Analysis of biometry and prevalence data for corneal astigmatism in 23239 eyes. J Cataract Refract Surg. 2010;36(9):1479-85. Comment in: J Cataract Refract Surg. 2010;36(9):1447-8; J Cataract Refract Surg. 2011;37(3):621; author reply 621.

2. Hoffer KJ. Biometry of 7,500 cataractous eyes. Am J Ophthalmol. 1980;90(3):360-8.

3. Grabow HB. Intraocular correction of refractive errors. In: Kershner RM, editor. Refractive keratotomy for cataract surgery and the correction of astigmatism. New Jersey: Slack Thorofare; 1994. p.79-115.

4. Frohn A, Dick HB, Thiel HJ. Implantation of a toric poly(methylmethacrylate) intraocular lens to correct high astigmatism. J Cataract Refract Surg. 1999;25(12):1675-8.

5. Koch D, Lindstrom RL. Controlling astigmatism in cataract surgery. Sem Ophthalmol. 1992;7:224-33

6. Shepherd JR. Correction of preexisting astigmatism at the time of small incision cataract surgery. J Cataract Refract Surg. 1989;15(1):55-7.

7. Osher RH. Paired transverse relaxing keratotomy: a combined technique for reducing astigmatism. J Cataract Refract Surg. 1989;15(1):32-7.

8. Lever J, Dahan E. Opposite clear corneal incisions to correct pre-existing astigmatism in cataract surgery. J Cataract Refract Surg. 2000;26(6):803-5. Comment in: J Cataract Refract Surg. 2000;26(6):789-90; J Cataract Refract Surg. 2001;27(1):7-8; J Cataract Refract Surg. 2000;26(12):1697-8.

9. Müller-Jensen K, Fisher P, Slepe U. Limbal relaxing incision to correct astigmatism in clear corneal cataract surgery. J Refract Surg. 1999;15(5):586-9.

10. Viesser N, Nuijts RM, de Vries NE, Bauer NJ. Visual outcomes and patient satisfaction after cataract surgery with toric multifocal intraocular lens implantation. J Cataract Refract Surg. 2011;37(11):2034-42

11. Chang DF. Prospective functional and clinical comparison of bilateral ReZoom and ReSTOR intraocular lenses in patients 70 years or younger. J Cataract Refract Surg. 2008;34(6):934-41. 
12. Pepose JS, Qazi MA, Davies J, Doane JF, Loden JC, Sivalingham V, et al. Visual performance of patients with bilateral vs combination Crystalens, ReZoom, and ReSTOR intraocular lens implants. Am J Ophthalmol. 2007;144(3):347-57. Comment in: Am J Ophthalmol. 2008;145(4):593-4.

13. Alió $J$, Piñero DP, Tomás J, Plaza AB. Vector analysis of astigmatism changes after cataract surgery with implantation of a new toric multifocal intraocular lens. J Cataract Refract Surg. 2011;37(7):1217-29.

14. Souza CE, Mucciolli C, Soriano ES, Chalita MR, Oliveira F, Freitas LL, et al. Visual performance of AcrySof ReSTOR apodized diffractive IOL: a prospective comparative trial. Am J Ophthalmol. 2006;141(5):827-32.

15. Woodward MA, Randleman JB, Stulting RD. Dissatisfaction after multifocal intraocular lens implantation. J Cataract Refract Surg. 2009;35(6):992-7.

16. Hayashi K, Manabe S, Yoshida M, Hayashi H. Effect of astigmatism on visual acuity in eyes with diffractive multifocal intraocular lens. J Cataract Refract Surg. 2010;36(8): 1323-9.

17. Wolffsohn JS, Bhogal G, Shah S. Effect of uncorrected astigmatism on vision. J Cataract Refract Surg. 2011;37(3):454-60.

18. Lane SS, Morris M, Nordan L, Packer M, Tarantino N, Wallace RB 3rd. Multifocal intraocular lenses. Ophthalmol Clin North Am. 2006;19(1):89-105.

19. Cezón Prieto J, Bautista MJ. Visual outcomes after implantation of a refractive multifocal intraocular lens +3.00 D addition. J Cataract Refract Surg. 2010;36(9):1508-16.

20. Entabi M, Harman F, Lee N, Bloom PA. Injectable 1-piece hydrophilic acrylic toric intraocular lens for cataract surgery: efficacy and stability. J Cataract Refract Surg 2011;37(2):235-40.

21. Liekfeld A, Torun N, Friederici L. [A new toric diffractive multifocal lens for refractive surgery]. Ophthalmologe. 2010;107(3):256;258-61. German.
22. Alfonso JF, Fernández-Vega L, Amhaz H, Montés-Mico R, Valcárcel B, Ferrer-Blasco T. Visual function after implantation of an aspheric bifocal intraocular lens. J Cataract Refract Surg. 2009;35(5):885-92.

23. Muñoz G, Albarrán-Diego C, Ferrer-Blasco T, Sakla HF, García-Lázaro S. Visual function after bilateral implantation of a new zonal refractive aspheric multifocal intraocular lens. J Cataract Refract Surg. 2011;37(11):2043-52.

24. Fujimoto K, Honda K, Wada YR, Tanaka M, Irie T. Four-year experience with a silicone refractive multifocal intraocular lens. J Cataract Refract Surg. 2010;36(8):1330-5.

25. Alió JL, Plaza-Puche AB, Piñero DP, Amparo F, Rodríguez-Pratas JL, Ayala MJ. Quality of life evaluation after implantation of 2 multifocal intraocular lens models and a monofocal model. J Cataract Refract Surg. 2011;37(4):638-48.

26. Viestenz A, Seitz B, Langenbucher A. Evaluating the eye's rotational stability during standard photography: effect on determining the axial orientation of toric intraocular lenses. J Cataract Refract Surg. 2005;31(3):557-61.

27. Zuberbuhler B, Signer T, Gale R, Haeflinger E. Rotational stability of the AcrySof SA60TT toric intraocular lenses: a cohort study. BMC Ophthalmology. 2008;8:8.

28. Montés-Micó R, España E, Bueno I, Charman WN, Menezo JL. Visual performance with multifocal intraocular lenses; mesopic contrast sensitivity under distance and near conditions. Ophthalmology. 2004;111:85-96.

29. de Vries NE, Webers CAB, Montés-Micó R, Ferrer-Blasco T, Nuijts RM. Visual outcomes after cataract surgery with implantation of $\mathrm{a}+3.00 \mathrm{D}$ or $+4.00 \mathrm{D}$ aspheric diffractive multifocal intraocular lens. Comparative study. J Cataract Refract Surg. 2010;36(8): 1316-22

30. Pomerance GN, Evans DW. Test-retest reliability of the CSV-1000 contrast test and its relationship to glaucoma therapy. Invest Ophthalmol Vis Sci. 1994;35(9):3357-61.

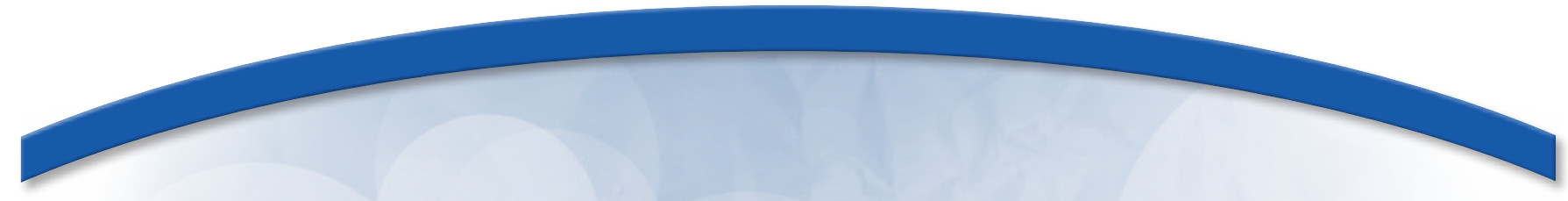

VII Congresso Baiano de Oftalmologia

10 e 11 de outubro de 2014

Hotel Sheraton

Salvador - BA

Informações:

Site: www.sofba.com..br

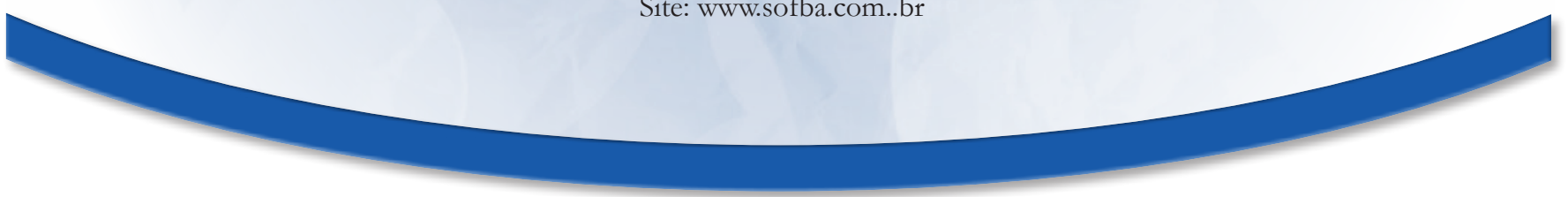

